\title{
CHALLENGES FOR ENVIRONMENTALLY SUSTAINABLE DEVELOPMENT OF NATURAL RESOURCES IN THE NAM OU KARST, NORTHERN LAOS
}

\section{IZZIVI OKOLJSKEGA TRAJNOSTNEGA RAZVOJA NARAVNIH VIROV NA KRASU NAM OU, SEVERNI LAOS}

\author{
Kevin KIERNAN ${ }^{1}$
}

\begin{abstract}
UDC 502.131.1: 504.062(598)

911.2:551.435.8(598)

Kevin Kiernan: Challenges for environmentally sustainable development of natural resources in the Nam Ou karst, northern Laos

A very low level of social and economic development in the Nam Ou karst is in part the result of its remoteness and rugged terrain. The karst poses both opportunities and challenges for environmentally sustainable land use beneficial to the small communities scattered through the area. Negative legacies of past human activity include soil erosion and a reduction in primary forest cover due to a long history of swidden agriculture, and environmental damage generated during wartime. A variety of natural resource development projects are now planned or under way, but progress towards true sustainability is impeded by the very limited resources available to address environmental concerns, which poses particular hazard for karst conservation and management.
\end{abstract}

Keywords:Karst, Sustainable development, Nam Ou, Laos.
Izvleček

UDK 502.131.1: 504.062(598)

911.2:551.435.8(598)

Kevin Kiernan: Izzivi okoljskega trajnostnega razvoja naravnih virov na krasu Nam Ou, severni Laos

$\mathrm{Na}$ krasu Nam Ou je zaradi razgibanega terena in odmaknjenosti raven družbenega in ekonomskega razvoja nizka. Kras predstavlja tako priložnost kot izziv za okoljsko trajnostno rabo prostora v korist majhnim ter razpršenim lokalnim skupnostim. Negativne posledice preteklih človekovih aktivnosti na tem območju vključujejo erozijo prsti in zmanjšanje površin primarnega gozda zaradi dolge tradicije požigalništva ter okoljske škode, nastale med vojno. Načrtovani ali v fazi izvedbe so številni razvojni projekti za razvoj naravnih virov, toda razvoj v smeri prave sonaravnosti ovira omejenost naravnih virov ki bi jih bilo mogoče varovati, kar predstavlja nevarnost za ohranjanje in upravljanje krasa.

Ključne besede: Kras, trajnostni razvoj, Nam Ou, Laos.

\section{INTRODUCTION}

The karst-rich Nam (river) Ou basin is one of the least populated parts of Laos (Fig. 1). Social and economic development remains very limited, a product not only of the area's relative remoteness but also past political instability and warfare that saw Laos become the most heavily bombed country on Earth, much of this onslaught impacting karst (Cummings \& Burke 2005; Kiernan 2010).
Sustainable development in any jurisdiction requires identification and inventory of key environmental assets and management challenges, properly informed decisions as to which proposals warrant support, and the formulation of effective management responses. However, these tasks pose particular difficulties in Laos where financial resources and specialist expertise are limited and

\footnotetext{
${ }^{1}$ School of Geography and Environmental Studies, University of Tasmania, Private Bag 78, Hobart, Tasmania 7001, Australia, e-mail: Kevin.Kiernan@utas.edu.au

Received/Prejeto: 23.7.2010
} 
Fig. 1: Location of study area and key sites mentioned in text. the understandable pressure for accelerated economic development has the potential to result in adverse environmental outcomes. Under such circumstances, particularly complicated and difficult environmental challenges such as those posed by karst environments (Yuan 1988; Kiernan 1988) are at risk of receiving little attention. This paper provides an introduction to some issues in relation to natural resource development and associated karst management considerations in the Nam Ou catchment.

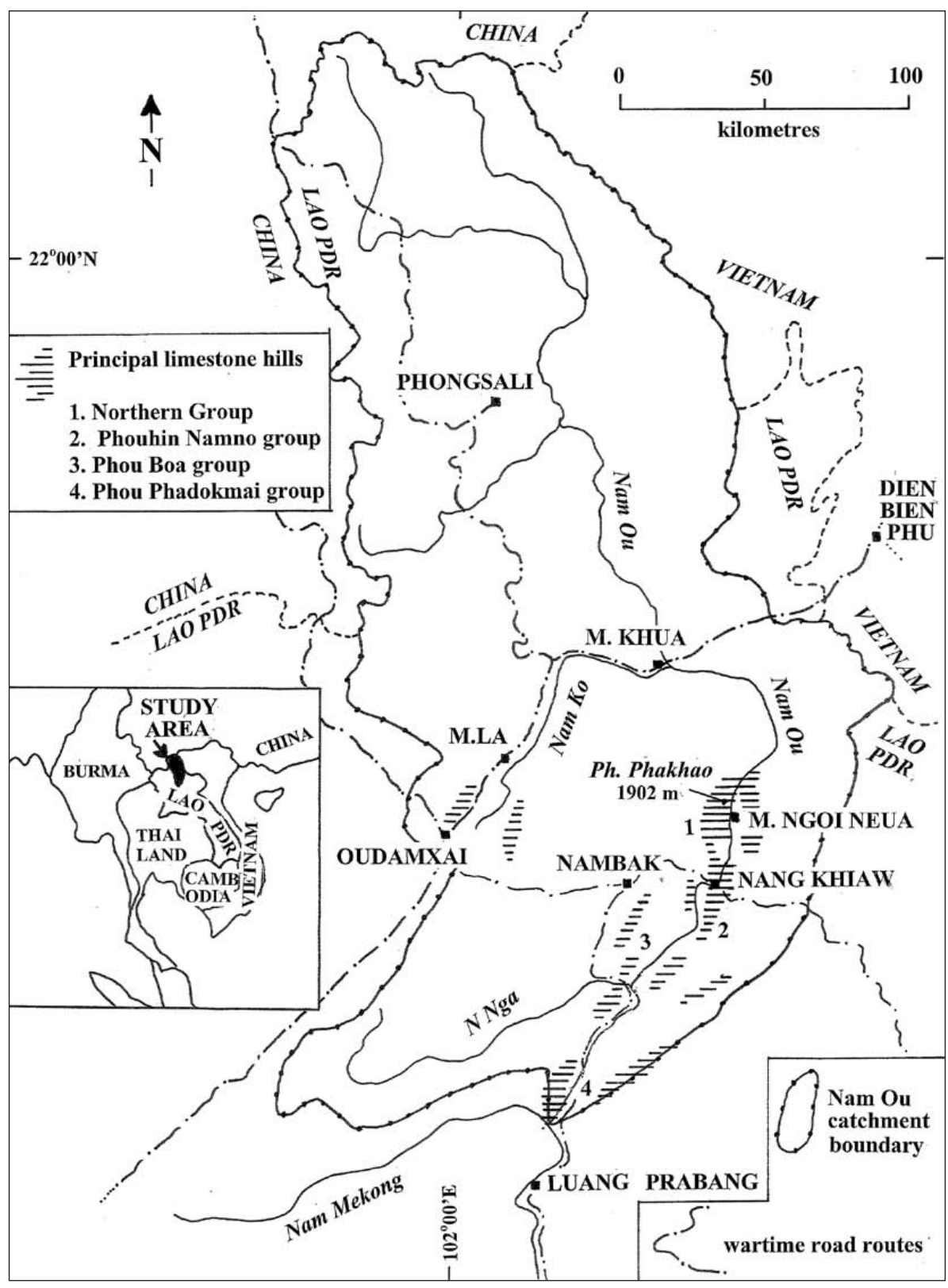

\section{STUDY AREA AND METHODOLOGY}

From its source in the far north of the Lao PDR the Nam $\mathrm{Ou}$ flows generally southwards to join the Nam Mekong (Fig. 1). The most conspicuous karst has formed in limestone of Carboniferous-Permian age that crops out downstream of $\sim 20^{\circ} 50^{\prime} \mathrm{N}$ but little research into this karst has been conducted. The maximum local topographic limestone relief is $\sim 1500 \mathrm{~m}$, karstic aquifers are well developed and numerous caves are known to exist (Dreybrodt \& Laumanns 2005a, 2005b, 2005c. Geologi- cal mapping remains incomplete and major springs and caves in some less conspicuously karstic terrain highlight the likelihood that limestone is considerably more widespread than initial visual impressions may suggest, while the likelihood of inter-stratal karst must also be recognised. Some karst phenomena may also occur further upstream in the Nam Ou basin where there are limestones of Devonian-Carboniferous age and possibly other limestone units in undifferentiated Triassic rock sequences in 
some uppermost tributary areas. Halite and gypsum beds in some non-carbonate sequences of Cretaceous-Jurassic age (LDGM 1991) may even add a further dimension to the karst management challenges to be anticipated in the Nam Ou basin.

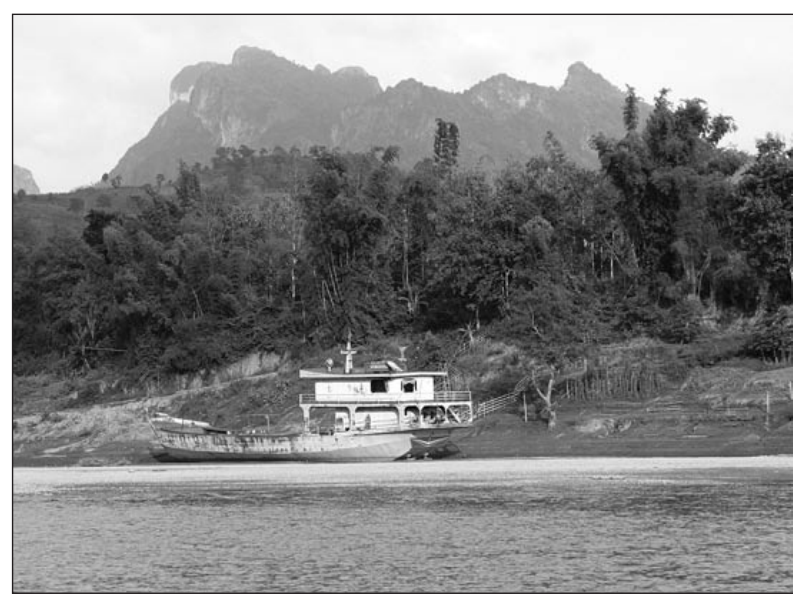

Fig. 2: Lower Nam Ou River near Phou Phadokmai. The river has long been the principle transport axis but new roads are now absorbing much more of this traffic (Photo: K. Kiernan).

Isolated villages are scattered among the narrow valleys that separate the mountains with smaller communities having become established on some of the mountains themselves. In the absence of roads, the Nam Ou has long served as a major transport artery, hence, the karst in this area has also borne the brunt of a variety of environmental impacts associated not only with providing resources for local requirements but also for more distant markets (Fig. 2). About one third of the Nam Ou catchment is still classified as being forested, $20 \%$ agricultural, and $1 \%$ urban, the largest town being Oudamxai (pop. $\sim 80,000$ ). The remainder of the basin comprises either disturbed former forest or steep rocky ground (Souphasay 2008). Pressures related to population growth, natural resource exploitation, infrastructure development and expanding commercial tourism are in- creasingly being superimposed on older ways of living in the Nam Ou landscape. The fostering of major road construction through northern Laos to facilitate exchange between the powerful regional economies of China, Vietnam and Thailand will compound both economic opportunity and also environmental hazards.

The aim of this study is to review the impact of past land uses in karst areas along the Nam Ou, the impact of present-day human activity, and the likely implications of potential future development projects. The fieldwork involved reconnaissance-level investigation of selected sites near Nang Khiaw, Pak Mong and Oudamxai, but the main focus was the topographic corridor through which the main channel of the Nam Ou flows. The impact of past and present land-use in the karst was assessed from inspection along the river between Phongsali and the Mekong and in the vicinity of some river-side villages. The condition of caves used for shelter, subsistence hunting and fishing, religious ceremony, housing of military personnel, sanctuary for citizens and government during war-time, and more recent tourism was also investigated. Observations on the ground surface focussed on the condition of soils and water-courses. The degree of past soil erosion was estimated from the vertical amplitude between the present ground surface and karren types that form beneath the soil surface, such as rundkarren, but which have since become exposed due to soil erosion (Trudgill 1976; Kiernan 1989). All physical measurements were made using a hand-held compass, tape and clinometer. Extensive photo-documentation of key sites and features supplemented written records obtained in the field. These field observations were placed in wider context by reference to the very limited literature available, coupled with consultation of topographic maps of 1: 100,000 scale and SPOT images available on Google Earth. Insight into proposed natural resource development proposals and their implications for local communities was developed from scant published and unpublished written sources, and from discussion with people in local villages.

\section{USE OF CAVES}

Comprehensive archaeological surveys of the Nam Ou caves are yet to be undertaken. By analogy with caves in neighbouring Vietnam (Reynolds 1990; Yi et al. 2008) and Thailand (Gorman 1972; Kiernan et al. 1988; Sidisunthorn et al. 2006), and further south in the Laotian provinces of Luang Prabang and Xieng Khuang (Sayavongkhamdy et al. 2000; White et al. 2009), there seems a strong likelihood of prehistoric archaeological sites being present along the $\mathrm{Nam} \mathrm{Ou}$, including Hoabinhinian assemblages and post-Hoabinhian material perhaps even including log coffins similar to those present in some caves in Thailand and Xieng Khuang (Middleton \& Kiernan 2010). Prehistoric use of caves inevitably implies anthropogenic impacts on cave environments but its leg- 
acy now often provides a cultural heritage dimension to the caves involved. If this likely cultural heritage is to be safeguarded it must first be properly identified, inventoried and researched and any management requirements recognised and implemented.

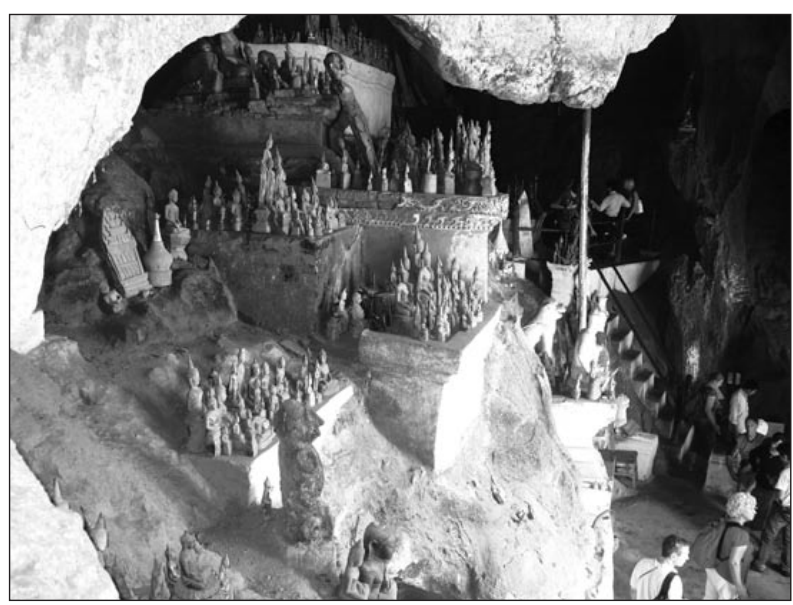

Fig. 3: The many ancient Buddha statues in the Pak Ou Caves, on the south bank of the Mekong opposite its confluence with the Nam Ou, highlight the religious significance of some caves in this area. The Pak Ou Caves now also attract large numbers of tourists visiting the nearby ancient Royal capital Luang Prabang (Photo: K. Kiernan).

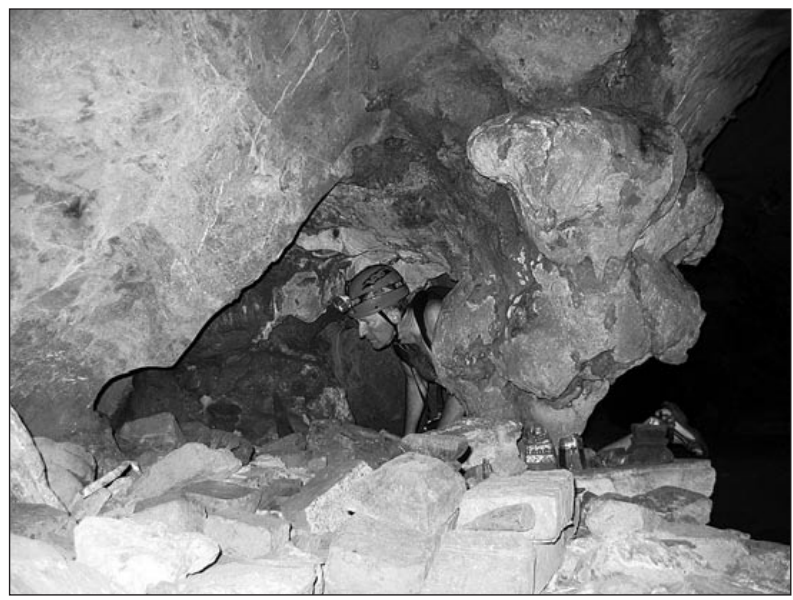

Fig. 4: Rubble from former cave temple and cave wall caused by wartime explosion in Tham Pha Kuang near Nang Khiaw, with more recently installed religious icons at this site (Photo: $\mathrm{K}$. Kiernan).

Thousands of ancient Buddha statues contained within the Pak Ou Caves, on the banks of the Mekong just opposite the point at which it is joined by the $\mathrm{Nam} \mathrm{Ou}$, highlight the long-term religious significance of caves in this area (Fig. 3). For example, Tham (cave) Panoi near Muang Ngoi Neua is sometimes used as a place of meditation by monks, and small Buddha statues are present both in its entrance and in a recess at its far end (Dreybodt \& Laumanns 2005a). Small passages just beyond the large entrance chamber of Tham Pha Kuang near

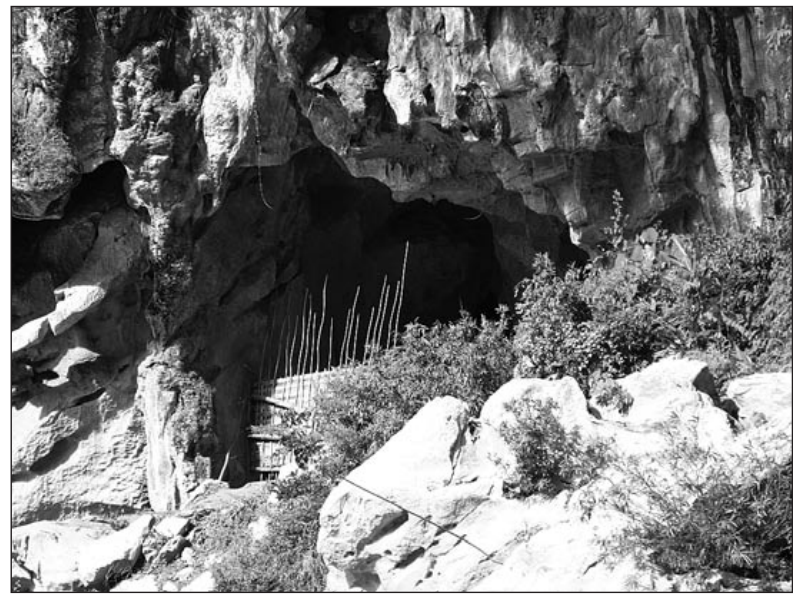

Fig. 5: A river-side cave entrance modified to enhance overnight shelter for fishers (Photo: K. Kiernan).

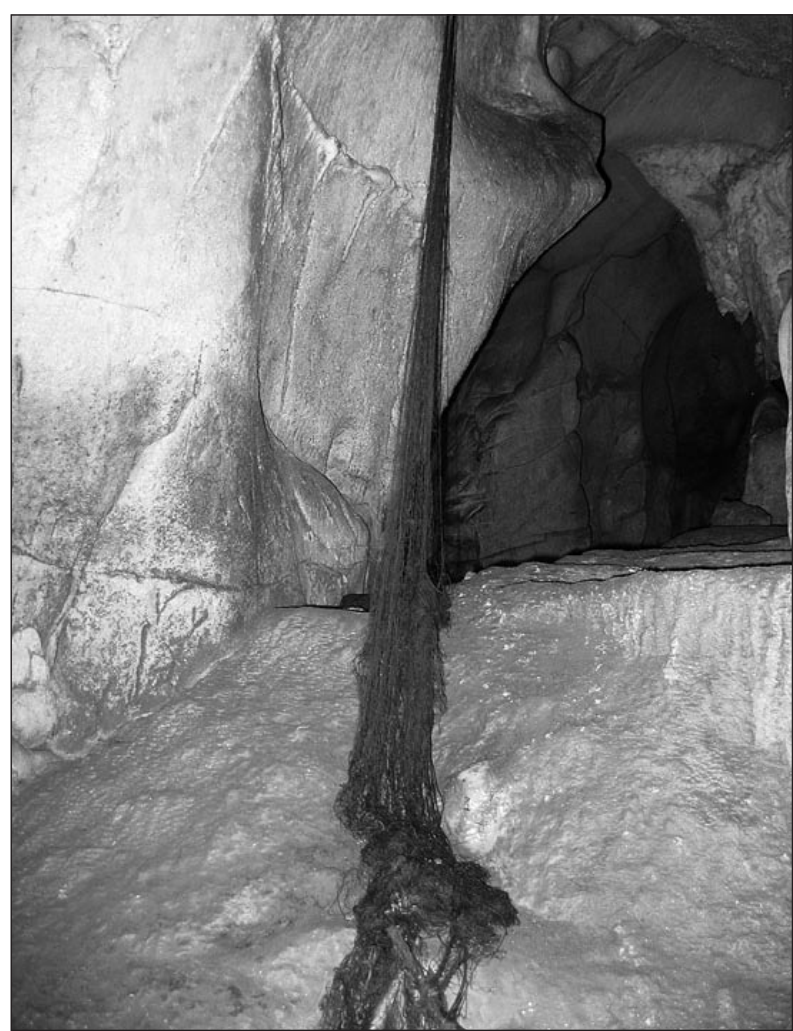

Fig. 6: Netting used for capturing bats in Tham Pageo (Photo: K. Kiernan).

Nang Khiaw are littered with brickwork, stucco rubble and broken statues from a previous religious structure, presumably destroyed when those in the cave were attacked by the wartime rocket fire that has also shattered 
and blackened rock in the cave entrance. Reinstallation of small shrines, including relocation of some fragments of the earlier structure, attest to some continuing religious significance (Fig. 4). Such use of caves for shelter during war-time, including the basing of soldiers within them and the shelling of cave entrances this has attracted, have further degraded the natural environmental condition of some other caves, even though some accrual of new cultural heritage significance is sometimes implied by such a history (Kiernan 2010b).

Continuing subsistence uses of caves along the Nam Ou includes the use of Tham Pasang on the banks of the Nam Ou for overnight shelter by fishers (Fig. 5), and the use of Tham Pageo for harvesting of bats for food, to which fishing nets strung across key passages to roosting sites attest (Fig. 6). Fish traps are also present in the Tham Kham stream bed. The consequences for cave environments include the impact of visits by individuals for whom the conservation of cave values is not a priority, such as widespread trampling of mud onto flowstone surfaces and some breakage of speleothems. There are also obvious consequences for the species targeted, but in the absence of baseline information on prior condition of the fauna accrued impacts are impossible to define. Use of caves for tourism is presently in its infancy but considerable potential exists provided the caves do not cease to be attractive due to degradation by other uses or by the manner in which tourist operations are themselves conducted.

\section{AGRICULTURE AND FISHING}

Food security has long been a widely pervasive problem throughout Laos, where drought and floods coupled with low levels of economic development and poorly developed communications infrastructure pose significant challenges. Food acquisition commonly accounts for over $60 \%$ of household spending, and poverty affects over $40 \%$ of the population in many rural areas such as those in karst areas along the Nam Ou. Farm productivity is typically low. Fish from the Nam Ou and some of its tributaries provide a large proportion of the protein intake for many village communities (Fig. 7). Localised flat land is the focus of agriculture (Fig. 8), while vegeta-

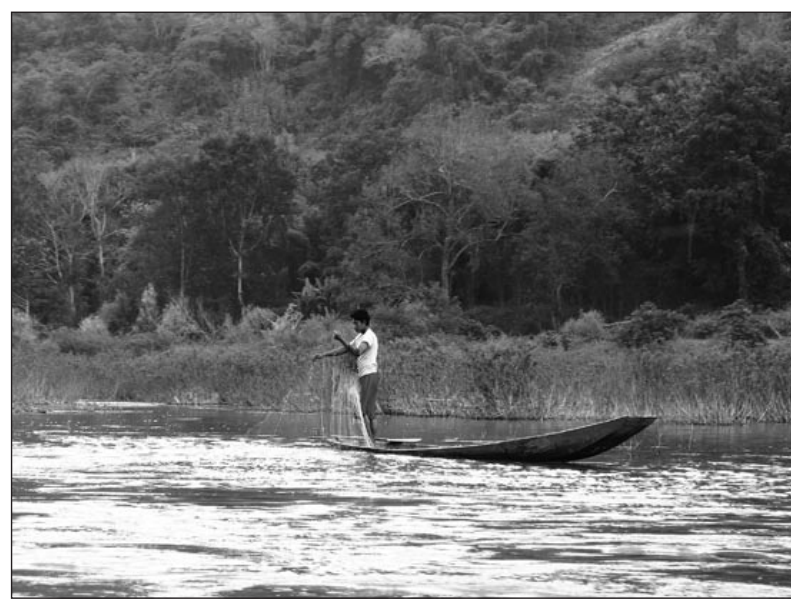

Fig. 7: Low technology fishing activity is a primary source of protein for many village communities along the Nam Ou. There are perhaps no images more emblematic of this area than that of a fisher casting their net from a canoe amid a background of limestone hills (Photo: K. Kiernan). ble cropping is also widespread upon freshly-deposited riverbanks silts immediately the water level drops after each wet season (Fig. 9). Much other agriculture involves

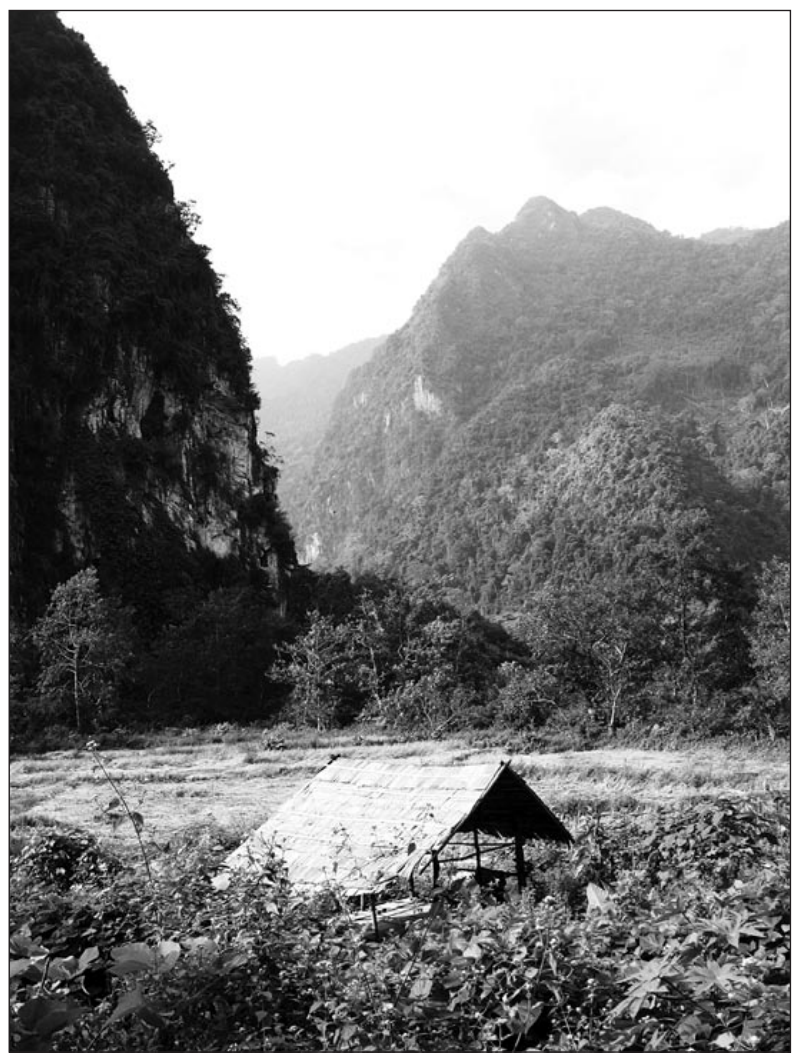

Fig. 8: Narrow alluvial plains between karst towers are an important location for rice production, which sometimes entails utilisation of water emerging from springs (Photo: K. Kiernan). 


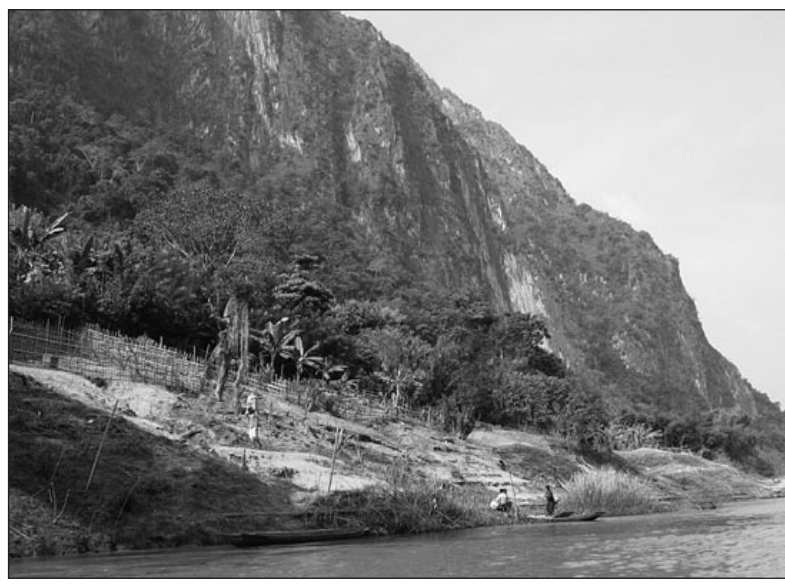

Fig. 9: Different vegetable crops are planted on the fresh riverbank silts as the level of the Nam Ou and many of its tributaries drops progressively at the end of each wet season (Photo: K. Kiernan).

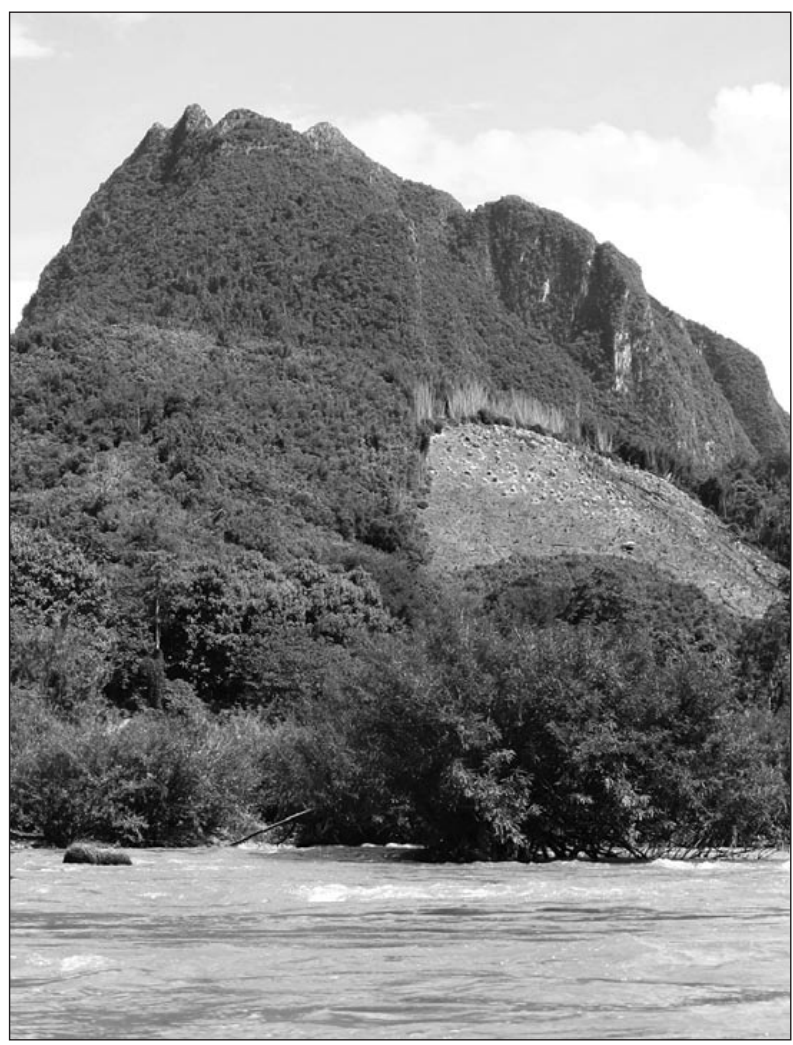

Fig. 10: Field recently cleared from secondary vegetation on very steep slope (Photo: K. Kiernan).

clearing and cultivation of steep hill slopes (Fig. 10) from which soil appears to be rapidly eroded due to this disturbance (Fig. 11). While permanent agriculture is largely confined to land with a gradient of $<5 \%, 70 \%$ of shifting cultivation occurs on slopes exceeding $20 \%$, often on soils that are unsuitable for annual crops and where terraces or contour cultivation that might ameliorate ero-

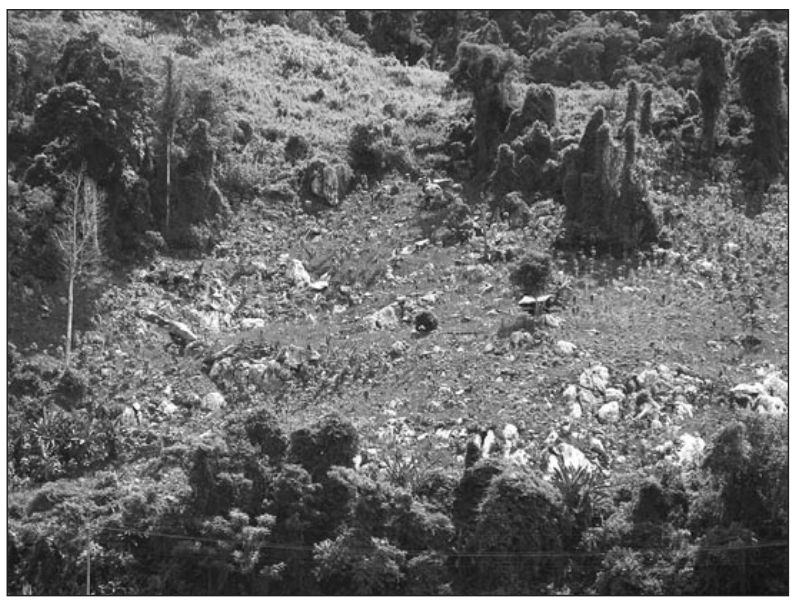

Fig.11: Progressive soil loss from steeply-sloping fields results in increasing exposure of large areas of limestone bedrock (Photo: K. Kiernan).

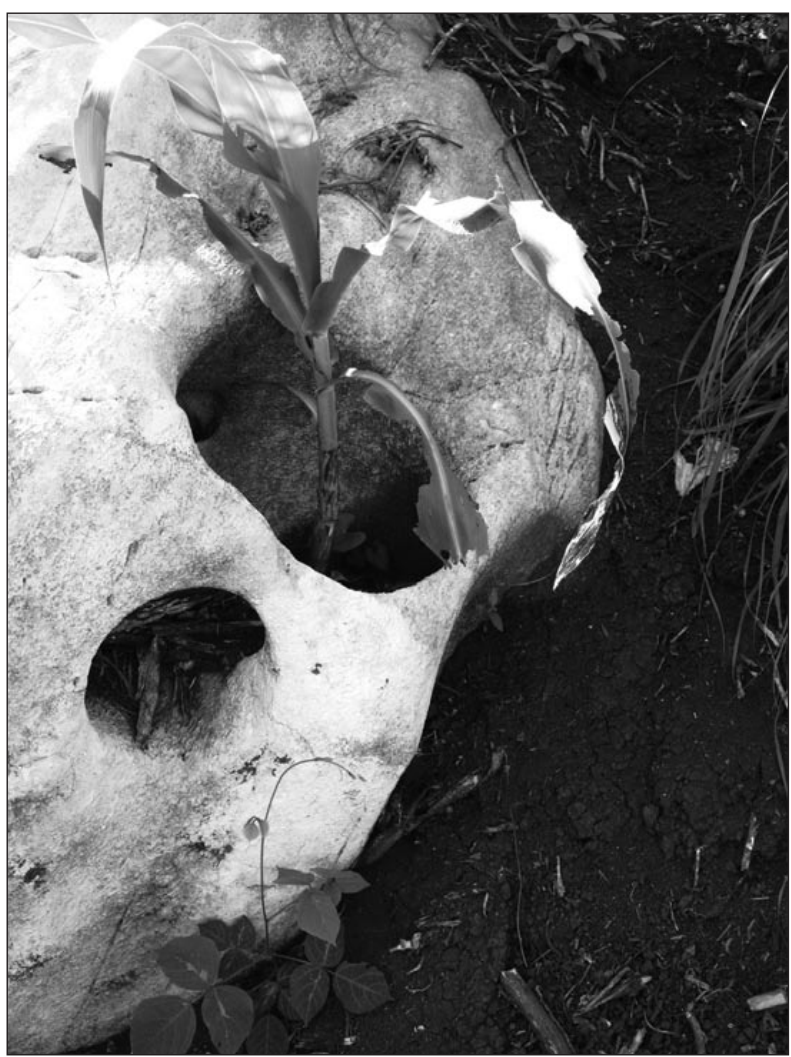

Fig. 12: Soil loss down-slope and into the epikarst progressively reduces the area in which crops can be planted, as at this site just upstream from Nang Khiaw (Photo: K. Kiernan).

sion are not employed (Thongmanivong \& Fujita 2006). The area suitable for planting is progressively reduced by this erosion (Fig. 12).

Examination of a small swidden in secondary forest a short distance upstream from Muang Ngoi Neua, revealed exposure of karren forms that develop beneath 


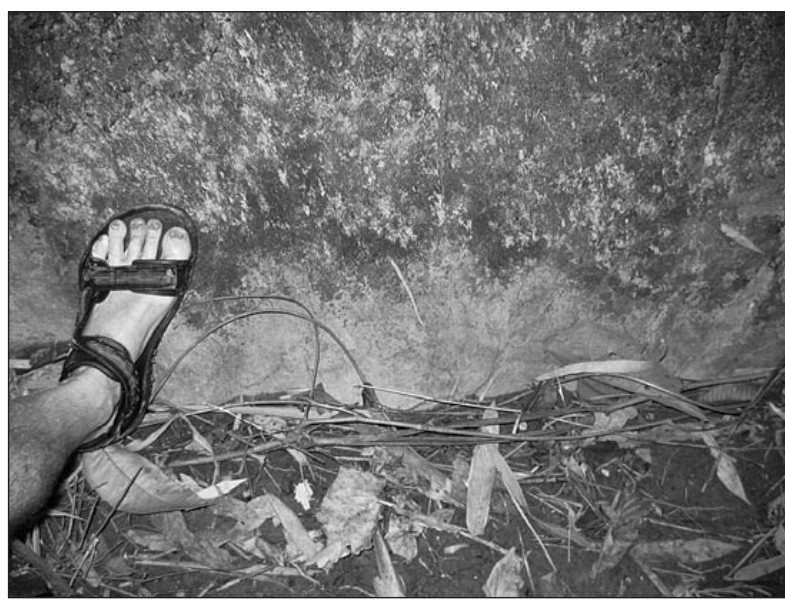

Fig. 13: That soil erosion is an ongoing process on swiddens is highlighted by this sharp demarcation between the darker coloured rock surface, caused by weathering and colonisation by lichen, and the lighter coloured rock surface down-slope that still bears remnant staining by soil colloids (Photo: K. Kiernan).

a soil or litter cover, such as rundkarren, and which only become subaerially exposed by erosion of that original cover. Rundkarren occurred $30-40 \mathrm{~cm}$ above the present ground surface. A sharpened micro-relief of 1-3 mm, comprising closely juxtaposed pock marks, and more angular incisions up to $1.5 \mathrm{~cm}$ deep, formed along structural weaknesses at varying orientations and of subaerial origin, was found superimposed on the exposed rundkarren in some cases. This suggests that at least a few decades have elapsed since the worst erosion. However, smoother rock surfaces, still stained by soil colloids, were evident on the lowermost $2-4 \mathrm{~cm}$ of some outcrops (Fig. 13), suggesting renewed soil loss into the epikarst as a consequence of the current cycle of swiddening.

However, swidden cultivation and associated soil erosion and sedimentation in karstic conduits is probably the product not only of food production but also opium poppy cultivation (Kiernan 1987). Limited cultivation to meet local demand was replaced by larger scale commercial production throughout Laos during the period of French colonial occupation when, during the Great Depression of 1929, France was able to balance its books using profits from its colonial opium monopoly (Issacs 1967). Forest clearing for poppy growing expanded further during the American War in Indochina when relationships with key but corrupt allies were maintained partly by the American government turning a blind eye to their production and sale of opium, while rampant heroin addiction among American GIs later provided a further market conducive to additional forest and land degradation (McCoy 1972). Following the war, stabilisation of the new communist government in Laos and its response both to the internal problems inherent with the

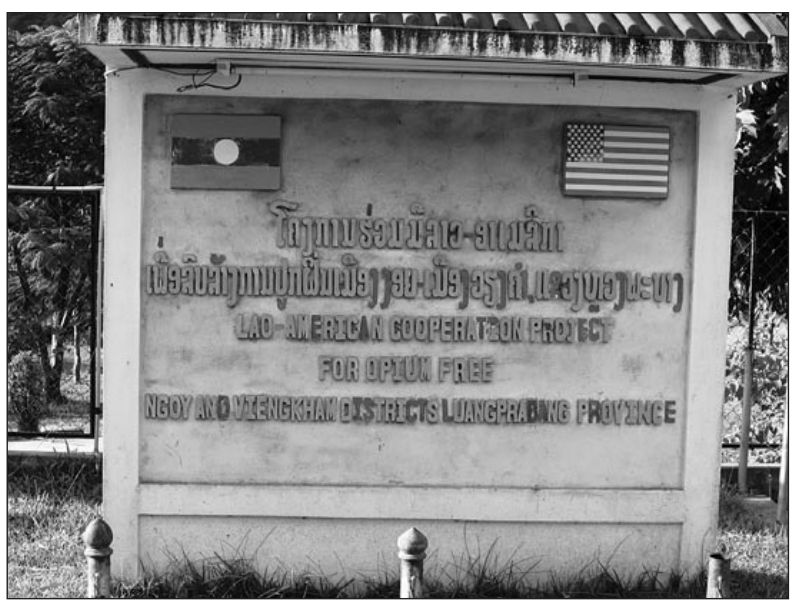

Fig. 14: Large scale opium poppy cultivation on steep limestone slopes has been responsible for considerable soil loss in the past, but is now relatively restricted. Occasional signs report the existence of active campaigns to reduce opium production, the bilingual format highlighting the perceived importance of ensuring visitors from outside Laos are aware that the issue is being addressed - this one reads: "Lao-American Cooperation Project For Opium Free Ngoy and Viengkham Districts Luangprabang Province" (Photo: K. Kiernan).

narcotics industry and also pressure from international interests, poppy production was reduced (Fig. 14). After signing of a memorandum of understanding on narcotics cooperation between Laos and the USA in 1989 production declined from 380 tons that year to 180 tons by 1993 , albeit partly driven by weather conditions, but in 1994 Laos still remained the world's third largest producer of opium. The total area devoted to poppies nationwide further declined from 26,800 ha in 1998 to 14,052 in the 2001-2002 season, when the greatest production in the Nam Ou basin was in Ngoi district where 28 villages produced $5,420 \mathrm{~kg}$ from 520 ha of poppy fields (LNCDCS 2002). Since 2002 national production has continued to decline, but the Nam Ou remains in the heartland of persisting poppy growing (UNODC 2007).

Present government policy is directed towards poverty elimination. Much depends upon raising farm productivity to achieve food self-sufficiency, crop diversification, fostering alternative ventures such as grazing, aquaculture and agro-forestry, the substitution of cash crop production for expensive importation, and developing the infrastructure and other requirements for improved market access. The focus of these initiatives is on the development of flatland agriculture and replacement of unsustainable slash and burn activity on steep slopes by more sedentary agriculture. Analysis of land-use change between 1993 and 2000 in four northern provinces indicates a reduction in areas used for traditional upland rice cultivation and swidden farming (Thong- 
manivong \& Fujita 2006). Fostering production of local handicrafts for sale to tourists represents another facet of this strategy (Fig. 15), although a major decline in visitor numbers associated with the 2009 Global Financial Crisis highlights the need for a broadly-based spread of such economic alternatives.

Community-managed farming and irrigation systems are fundamental development strategies being pursued (Anonth 2002). While laudable, these measures also imply environmental management challenges that need to be addressed effectively if excessive collateral environmental damage is to be avoided and wider or longer term potentialities are not to be compromised. The acquisition of land resource information has typically focused on slope angles, altitude, soil conditions and existing land use, with the prevalence of unexploded ordnance (UXO) an unwelcome extra consideration (Anonth 2002). However, in karst areas there is also a need for detailed understanding of the karst and its potential implications in terms of the opportunities it offers and which schemes and practices offer the best prospects for sustainability.

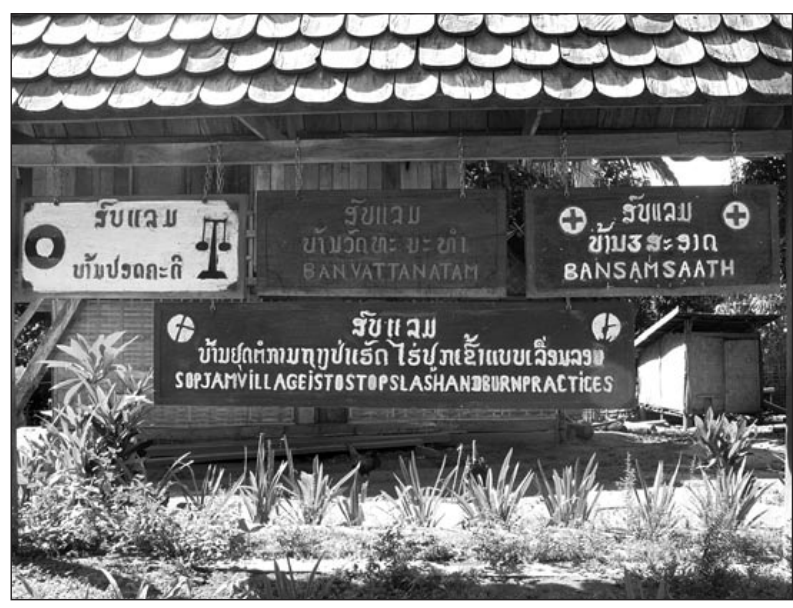

Fig. 15: The development of tourism allows the possibility of providing accommodation and guiding services, and selling village handicrafts, as alternatives to more environmentally damaging livelihoods, as at this village where a sign bears an un-punctuated English translation reading "Sop Jam Village is to stop slash and burn practices". However, this may not always be a panacea as shown by a downturn in tourism due to the 2010 Global Financial Crisis that significantly affected this particular community (Photo: K. Kiernan).

\section{FOREST RESOURCES AND MANAGEMENT}

Forests provide timber for construction and fuel but also a wide variety of other products including subsistence foods, fibre, medicines and locations for livestock grazing. Soil erosion and sediment transfer occurs not only where the trees are cut but also along log transport routes (Fig. 16). Just over one third of the Nam Ou basin is presently classified as forested and there are significant areas

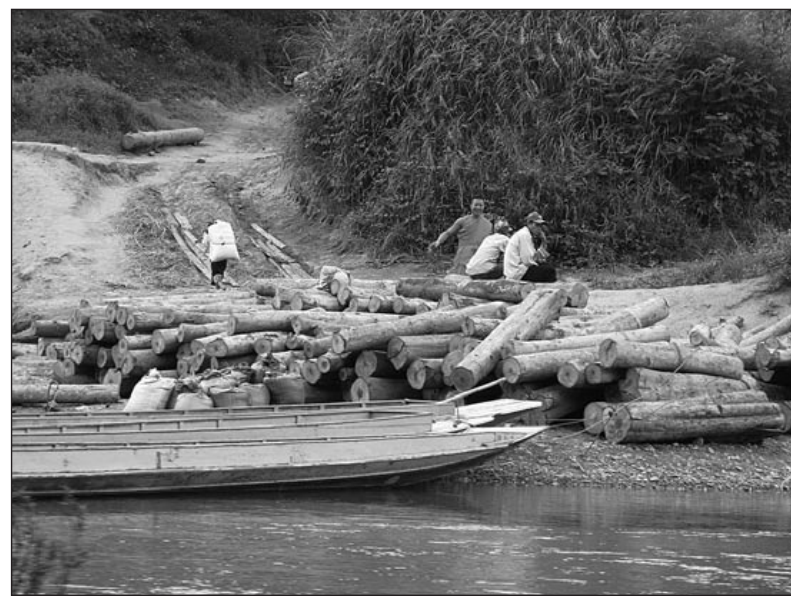

Fig. 16: Logging, whether legal or illegal, involves impacts on soil and water resources both at logging sites and along transport routes (Photo: K. Kiernan). of disturbed former forest. In the upstream extremities remnant native forests are predominantly dry evergreen and semi evergreen. Very little natural forest remains on slopes of $<20 \%$. Disturbance of remaining forest is most pronounced downstream of Phongsali but is also very significant along the river further upstream and along many tributaries. Within the karst areas intact forest is largely confined to the steepest slopes where access is most difficult (Fig. 17).

An assessment of land use change in four northern Lao provinces between 1993-2007 suggests that forest cover has increased since 1997, however, the available spatial data did not permit that study to discern the quality of the regrowth (Thongmanivong \& Fujita 2006). Reconnaissance inspection during fieldwork for the present paper suggests regrowth is often by more scrubby structure than is typical of relatively undisturbed forest nearby, and entails a much larger component of vine thickets. The small size of the regrowth on relatively old swiddens also suggests regeneration by trees, as opposed to fast-growing bamboo, may be relatively slow. Deliberate planting of forest is becoming prevalent where a developed market is accessible to would-be producers (Anonth 2002). Elsewhere in northern Laos the improvement of roads and formalisation of international trade 
and capital from China is resulting in increased planting of rubber trees (Thongmanivong \& Fujita 2006). Some planting of rubber trees has already occurred around riverside villages and larger settlements such as Nang Khiaw. Where degraded land is afforested this may help stem soil loss if the trees themselves are not harvested.

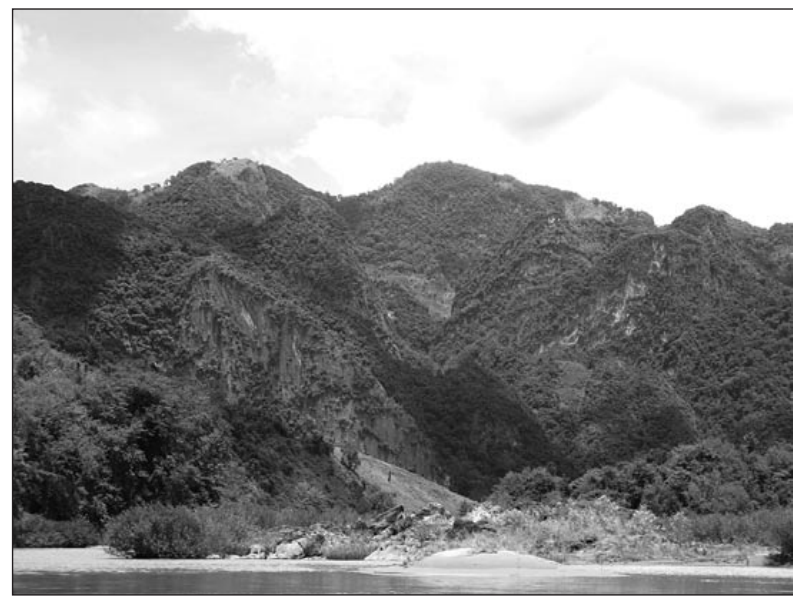

Fig. 17: Vegetation cutting and associated forest degradation (light-coloured areas) has occurred even to the summits of some limestone mountains. (Photo: K. Kiernan).

\section{MINING}

Quarrying of limestone occurs south of Nambak, largely for cement production, and some quarrying also occurs around Oudamxai. Known metallic ore deposits in the Nam Ou basin include copper, lead, gold and iron but detailed exploration has been minimal, resource extent is undetermined, and no large-scale mining has been initiated. Presently, mining along the Nam Ou itself is restricted to very small scale artisanal gold mining in placer deposits, conducted only during the dry season when water levels are low. This enterprise forms an important supplement to the income of some local farming families who lack any capacity for capital investment (Kazuki 2006). Typically the men excavate material using shovels or chisels and the women and children transport the sacks for panning and sluicing (Fig. 18), with gold extraction undertaken at home. In a few cases small petroldriven compressors allow one individual equipped with an air-pipe and face mask to operate at shallow depth on the river bed.

These artisanal miners commonly escape examination by the authorities due to limited official manpower and resources, hence, no environmental standards can be enforced. Although scars from small-scale riverbed mining are likely to be erased in the next wet season, other aspects of such operations pose additional concerns. For example, because gold purity is typically low some miners utilise mercury to amalgamate it, thus posing risks of environmental contamination, a particular concern should mining occur along tributaries that sink into karst. Miners on ephemeral islands around the Mekong/Ou confluence often add mercury at the panning stage but

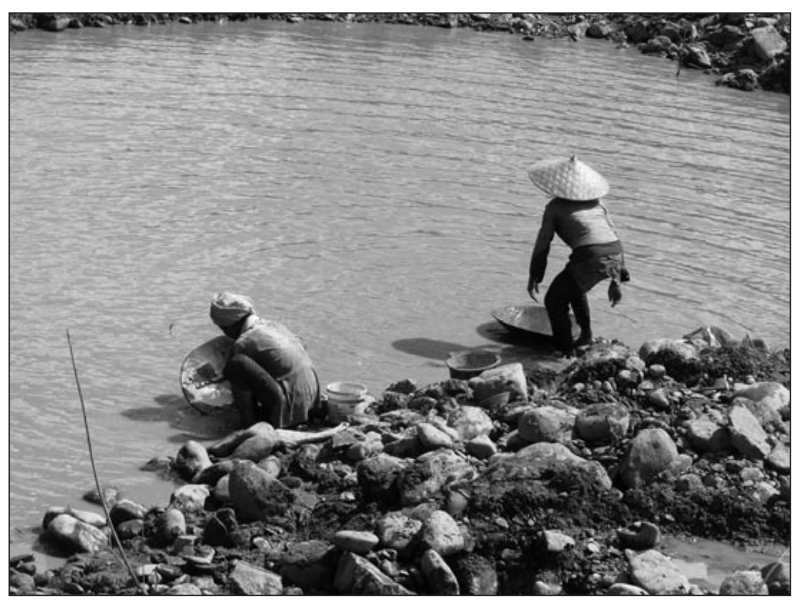

Fig. 18: Villagers panning for gold along the Nam Ou during the dry season (Photo: K. Kiernan).

some villagers along the Nam Ou eschew mercury and instead employ gravity separation of panned and sieved material after heating it, possibly due to larger gold size. Those using mercury generally then heat the amalgam in their homes, evaporating and potentially inhaling the mercury in the process of extracting the gold. A typical household may produce 10-40 grams of gold per year in this area (Kazuki 2006). Organisation and legalisation of artisanal miners would facilitate increased production through sharing of mechanised resources but this may in turn imply accentuated environmental impacts. Some localised use of excavators by larger operators also occurs and this can cause significant re-arrangement of stream bed configuration, sometimes creating hazards for those reliant upon the river as a transport route (Fig. 19).

Should large scale ore mining eventuate, environmental impacts associated with the supply of energy, transport and perhaps on-site processing of ores, housing for workers and waste disposal will need to be addressed in addition to the more fundamental mining impacts such as rock mass removal, spoil stabilisation and acid mine drainage. Such impacts may have serious implications in the karst areas. Although the Lao government's Science, Technology and Environment Agency (STEA), an arm of the Prime Minister's Office, is charged with conservation and pollution control, available resources limit its capacity to monitor and ensure compliance with its directives (Kazuki 2006). Conflicts may arise in future 


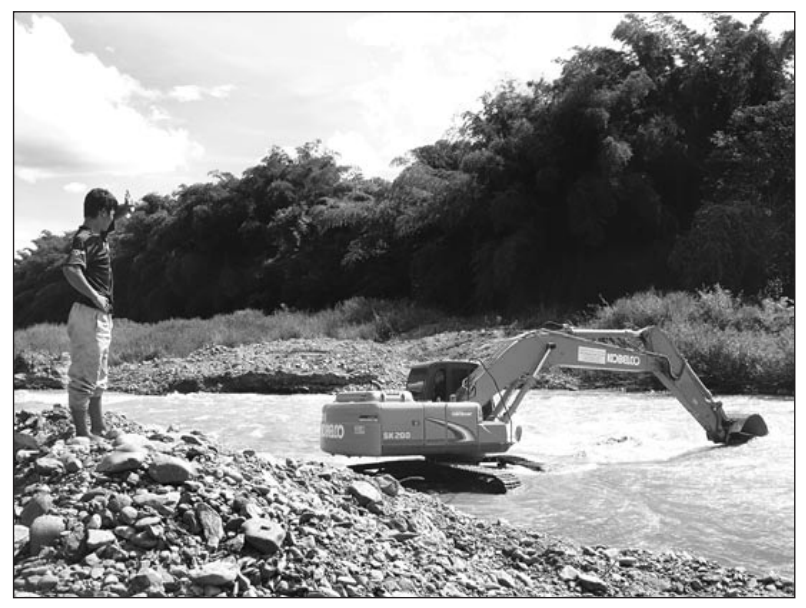

once geological exploration is more advanced should valuable mineral resources be located inside the perim-
Fig. 19: Larger scale, mechanised alluvial gold mining entails greater disturbance of channel beds and release of sediment plumes. Here a commercial boat operator delayed by channel derangement negotiates with a mechanised alluvial gold miner to re-open the navigable channel to allow his own enterprise to continue (Photo: K. Kiernan).

eters of proposed hydro-electric reservoirs, requiring decisions to be made regarding the future of dams that may in the meantime have caused far more widespread environmental damage than the footprint of a subsequent mine and its supporting infrastructure. This might again have major implications for karst environments and their sustainable utilisation.

\section{WATER RESOURCE DEVELOPMENT}

\section{AVAILABLE WATER RESOURCES}

The surface water resources of the Nam Ou basin sustain natural environmental values and provide key ecosystem services such as water for drinking, agriculture, fisheries and energy production. Laotian drainage systems contribute $\sim 35 \%$ of the total discharge down the Mekong; hence, exploitation of this water also has regional implications for downstream communities reliant on the Mekong. Mainstream discharge and water quality is highly dependant upon management of headwater areas throughout Laos and particularly along such major tributaries as the Nam Ou. Groundwater is also a significant consideration, especially in the karst areas. The Nam Ou flows predominantly from the Annamian granites, metamorphic and Palaeozoic sedimentary rocks, that contain local aquifers, onto the limestones and non-carbonate clastic sediments of the Indosinian region in which very major groundwater resources exist. Groundwater resources associated with the more recent Mekong sediments are of lesser consequence (IMC 1986). While there may be considerable local knowledge of karst springs and caves, these remain very poorly documented and specialist studies of karst hydrogeology are particularly lacking. Detailed information regarding aquifer structure and function, water quality, potential yield and associated management issues required to underpin karst groundwater exploitation on a sustainable basis is seriously deficient along the Nam Ou.

\section{IRRIGATION}

Rice is the principal food staple and improving the productivity of suitable land hinges in part on improving irrigation. Prime targets are flatlands suitable for intensive cropping but development of suitable systems to foster agro-forestry as an alternative to slash and burn agriculture on steeper sites is also important, particularly in remote mountain settings where flatland is limited or nonexistent (Anonth 2002). The oldest maintained irrigation structures in the Nam Ou karsts utilise timber, rock and earth to effect diversions. Most facilities in remote areas involve gravity-driven systems servicing small areas $(<100 \mathrm{ha})$. Large scale pumping is generally lacking, although some small scale pumping to very localised stream-side destinations does occur. Irrigation in this karst implies redirection of flows either from upstream of water-sinks, from karst windows, or from downstream of springs. The first two options would imply interference with karst hydrology but the latter is of less concern, as for example, in the Nam Ngoi Valley where a stream that emerges from Tham (cave) Kham has been canalised and re-directed across the local rice fields with no obvious impact on the karst.

\section{HYDRO-ELECTRICITY}

Micro hydro-electricity generation has been developed locally using small run-of-the-river installations on some tributary streams, but in some cases this in- 
volves karst streams that flow across the surface only intermittently, such that generation is irregular. Floating in-stream generators have been established locally in the main channel of the Nam Ou but these are prone to damage by floods or floating debris (Fig. 20). Larger centralised systems to provide electricity to towns and villages are lacking. The potential for very large-scale generation of hydro-electricity from the Mekong and such large tributaries as the $\mathrm{Nam} \mathrm{Ou}$ is considerable. The presently limited economic and social development in Laos, and the very large contribution of foreign aid to the Lao economy, allows the potential for aid donors to exert pressure upon the national government of Laos to give priority to the economic gains available from large scale hydro-electric development. This has given rise to proposals that Laos should become the "Battery of Asia". However, while this approach may meet the economic aspirations of rapidly industrialising neighbouring nations and the economic priorities of the national government, the impact upon local communities along the Nam Ou, including those displaced by artificial reservoirs, may not always be positive.

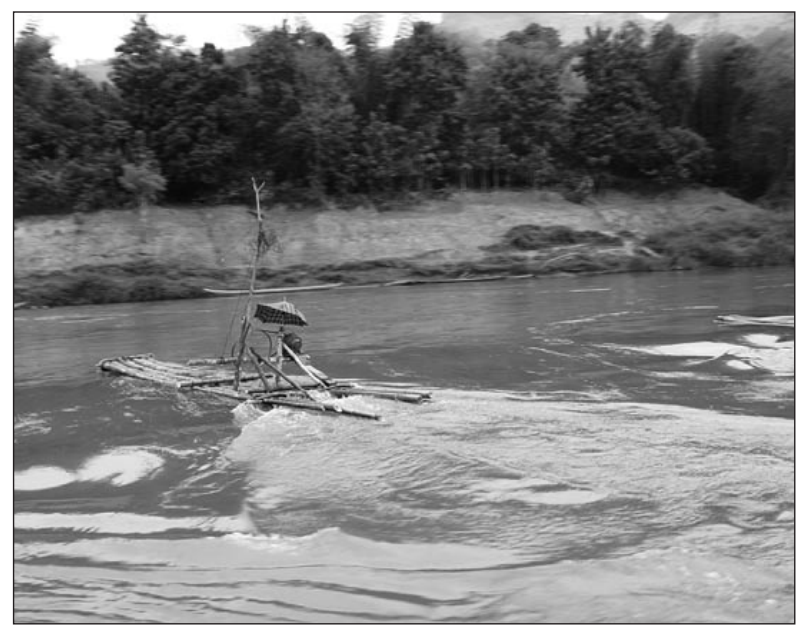

Fig. 20: In-stream micro hydro-electricity generation involving installation of small generators on moored rafts. Considerable potential exists for further such micro hydro generation to provide electrical energy for local communities (Photo: K. Kiernan).

One proposal involves a major dam on the Mekong $\sim 2 \mathrm{~km}$ upstream from its confluence the $\mathrm{Nam} \mathrm{Ou}$ and hence not flooding back into the Nam Ou itself, but the writer has encountered another map of uncertain veracity that depicts a potential damsite on the Nam Mekong between the Nam Ou confluence and Luang Prabang. Although the latter would seem a questionable prospect given the topography and highly karstic perimeter of any artificial reservoir here, other proposals have the potential to impact heavily on the natural environments of the Nam Ou basin. The proposed Nam Ou Cascade involves construction of 7-8 projects as a joint venture between Sinohydro of China (90-75\%) and the Government of Laos (10-25\%), focused in Phongsali province. A Project Development Agreement was signed between Sinohydro and the Lao government on 15 October 2007, and the following month Sinohydro announced that it had signed an agreement to sell $90 \%$ of the energy to Thailand, implying a requirement to construct a transmission corridor right across some of the wildest parts of northern Laos. A 30\% escalation of construction costs led to proposals in July 2008 for re-negotiation of the purchase price with the Electricity Generation Authority of Thailand (EGAT) (Vientiene Times 30 July 2008). Planned total installed capacity is 1, 200, 000 kilowatts and the total estimated cost is $\sim$ \$US 2, 000,000,000 (Sinohydro 2010).

Nam Ou 8 is the largest and most upstream of the proposed dams and is likely to be constructed first, followed by $\mathrm{Nam} \mathrm{Ou} 5, \mathrm{Nam}$ Ou 3 and $\mathrm{Nam} \mathrm{Ou} 2$. Nam Ou 8 would inundate $\sim 300 \mathrm{~km}^{2}$ including parts of the Phou Dene Din National Biodiversity Conservation Area. It would displace $\sim 7,000$ people and have other direct effects on $\sim 50,000$ people. This project lies upstream of the main karst, and although the potential exists for some karst to have also formed in other carbonate units in the development area the technical difficulties recognised during geological studies undertaken during the 1990s by USA consultants Pacific Resources related mainly to faulting. Depending upon operational factors there may nevertheless be some potential for impacts on the major karst downstream, because evolution and continued natural functioning of the karst aquifers are both linked to high river levels during the wet season when backflooding occurs into karstic conduits in the river-banks, alternating with dry season low river levels that expose open cave systems that allow the hinterland karst to drain freely into the river. A more consistent flow regime stemming from controlled release from dams upstream may intervene in this natural order with implications for aquifer function, any cave biota that may have evolved in the context of this natural order, and perhaps human access into some caves. The presently very limited documentation of caves makes it difficult to access the severity or otherwise of such potential impacts. That environmental safeguards appear to be receiving little consideration during initial access construction (Fig. 21) is not reassuring.

Construction of further dams within or below the known karst areas would clearly imply their inundation. It is difficult to obtain information as to the detail of plans or aspirations that exist, indeed there is a widespread local perception that very little information 
has been released. One document (IRO 2010) indicates dam-site place names and planned normal storage water levels (PSWLs) that include at Phathung, the name of a mountain $11.6 \mathrm{~km}$ from the Nam Ou-Mekong confluence (dam height $55 \mathrm{~m}$.; normal storage water level $305 \mathrm{~m}=25 \mathrm{~m}$ above the natural river bed); another dam further upstream at Huai Kan (height 48 m; NSWL 320 $\mathrm{m}=+17 \mathrm{~m}$ ); another at Ngoi Nua (dam height $69 \mathrm{~m}$; NSWL $320 \mathrm{~m}=+50 \mathrm{~m}$ ); and another at Muang Khua (dam height $47 \mathrm{~m}$; NSWL $375 \mathrm{~m} .=+20 \mathrm{~m}$ ). This suggests possible drowning of most of the karst downstream of the Muang Khua dam site. Flooding the landscape to $50 \mathrm{~m}$ depth in the Muang Ngoi area, for instance, would inundate large areas of karst and have major implications for aquifer function and karst-dependent natural and cultural values.

Any construction of dams in the limestone areas is obviously complicated by the difficulties inherent in ensuring water-tight storages on karstic substrates. While such challenges are now a well-known issue for water resource developments in karst areas, their resolution requires the formulation of case-specific solutions, for which a very detailed understanding of site conditions is a fundamental requirement. Appropriate expertise, sufficient lead time and adequate resourcing of investigations are all critical. Achieving satisfactory results can still be difficult, and failures may still occur (Ford \& Williams 2007). Leakage through solution cavities can be extremely expensive to address and such efforts are not always successful, while other potential hazards include ground surface subsidence, derangement of karst drainage by back-flooding of subsurface conduits, and profound effects upon cave-dwelling biota (Milanović 2004). In the Nam Ou case, particular caution may be warranted given that much delivery of foreign aid involves a requirement that business enterprises from the donor nation be employed to undertake the work. Although this may temporarily bring in valuable expertise, such arrangements are not always to the advantage of the recipient where very complex tasks with unexpected and expensive post-scripts may be entailed, such as dam construction on karst.

\section{DISCUSSION}

The Nam Ou environment meets, or has the potential to meet, many important human needs such as those for fresh water, fish spawning, wild food, building materials, local medicines, shelter, agrobiodiversity, pharmaceuticals and genetic materials (Dudley et al. 2010). More widely, ecosystem services that stem from the present condition of the Nam Ou basin help mitigate environmental risks such as those posed by flooding or drought further downstream. But notwithstanding the benefits that communities along the Nam Ou may derive from the ecosystem services their natural environment delivers, and the genuine advantages that may flow to them from the far-reaching nature conservation initiatives such a remarkable place undeniably warrants, this is a population that cannot reasonably have a continuation of its present disadvantage imposed upon it, and which consists of individual human beings who lack the economic capacity to bear costs associated with nature conservation that could be considered entirely reasonable in more advantaged western societies. But the environmental impacts now already being generated by construction of

Fig. 21: Major new road construction alongside the Nam Ou near Muang Khua, involving large volumes of sediment being displaced into the river channel (Photo: K. Kiernan). major new roads to provide the infrastructure that might facilitate the transformation of aspirations for advancement into a more prosperous future (Fig. 21) provide warning of the inevitable costs should single-mindedness and under-resourcing of necessary environmental studies prevail in the development quest.

While improving the circumstances of the people of the Nam Ou karst is of the highest priority, to do so without unjustifiable environmental cost also being incurred requires very thoughtful and culturally sensitive strategy development that is informed by excellent geographical

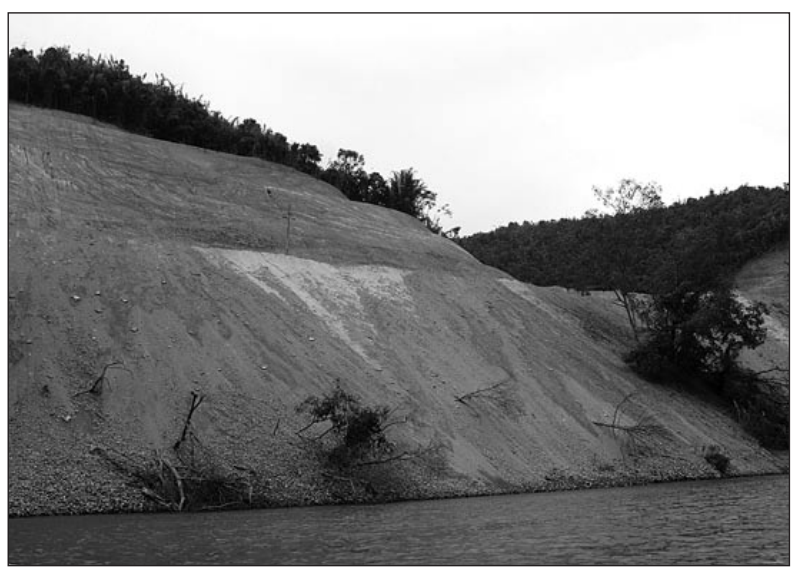


inventory, detailed understanding of site-specific natural system function, and rigorous social and economic insight, followed by exceptionally careful implementation. The inherent vulnerability and limited resilience of karst areas is now well known, as is their complexity and the practical difficulties entailed in the inevitably lengthy process of karst environmental inventory and analysis. These factors make truly sustainable development in karst-lands extremely challenging at the best of times, hence its achievement demands a major commitment of time, specialist expertise and economic resources. All three of the latter are lacking in present day Laos.

The Nam Ou karst has long borne witness to past colonial fantasies, whether glimpsed through hazes of opium smoke or through later hazes of bomb smoke; it is now being darkened by the shadows of equally colonial aspirations that would transform it from the victim of wartime battery to instead become the battery of Asia. There is a common tendency for narrow sectional goals to be forcefully promoted as being desirable overall national goals, almost by some unspoken definition. But dominating a national economy by building dams as if there were no other path to the well-being of a people may well cause significant disadvantage to the very local communities who are most in need of assistance. The alternative is to help shape environmentally sustainable economies for those people rather than to disrupt their lives yet again, or even to up-root them entirely from their traditional home-lands at the behest of outside interests.

The baguettes and bombs of the past are now also being replaced by brochures promoting putative wilder- ness experiences in someone else's backyard. While there are undoubted benefits to be derived from expanded tourism, it also requires cultural sensitivity and that the caves and karst landscapes that would form its backbone be properly researched and understood, so that decisions regarding particular sites are fully informed, soundly based management protocols are developed and effectively implemented, and site condition can be monitored and management adjusted as the need may arise. The impact of the 2009 Global Financial Crisis on tourist numbers in this part of Laos is also a salutary reminder of the vagaries of tourism and the need not to put all the eggs in the one basket, but rather to embrace a range of strategies. For example, in addition to meeting local needs, agricultural initiatives in the Nam Ou karst could become models for testing and demonstrating the combination of carbon capture with food production, for the reduction of $\mathrm{CH}_{4}$ emissions through improved techniques for rice cultivation, livestock and manure management (Lal 2004; IPCC 2007), and for the restoration of degraded land. But all such possibilities require a concerted commitment of goodwill, expertise and resources, and in this case these challenges arise in an environment where karst is a spectacularly dominant presence. Whether it be the fate of the Nam Ou to be the focus of massive hydro-electric development to meet the aspirations of neighbouring nations, or to have an alternative future that instead is more cognisant of local communities, there is a critical need for a very detailed understanding of the karst. This understanding cannot be developed overnight, and it will not be developed unless a start is made on the task.

\section{ACKNOWLEDGEMENTS}

I am grateful to Greg Middleton for his company and assistance during the 2008 field-trip, and to Dr Peter McQuillan for comments on a draft of this paper. 


\section{REFERENCES}

Anonth, K., 2002: Land and Water Investment in the Lao PDR. FAO Corporate Document Repository. Proceedings of the regional consultation, Bangkok, Thailand, 3-5 October 2001. RAP publication 2002/09.- [Online] Available from: http://www.fao. org/docrep/005AC623E/ac623e0h.htm [Accessed 15 June 2010].

Cummings, J. \& A. Burke, 2005: Laos. Lonely Planet, Footscray.

Dreybodt, J. \& M. Laumanns, 2005a: An overview of caving regions in northern Laos.- [Online] Available from: http://www.laoscaveproject.de/Laos\%20 UIS\%20Paper\%202005.pdf [Accessed 30 June 2007].

Dreybodt, J. \& M. Laumanns, 2005b: Northern Laos Christmas 2002. Expedition to Maung Ngoy and Luang Prabang, Lao PDR.

Dreybodt, J. \& M. Laumanns (eds.), 2005c: The unknown north of Laos. Karst and caves of the provinces Luang Phrabang and Luang Nam Tha.- Berliner Hoehlenkundliche Berichte, 15, pp. 135, Berlin.

Dudley, N., Stolton, S., Belokurov, A., Krueger, L., Lopoukhine, N., MacKinnon, K., Sandwith, T. \& N. Sekhran (eds.), 2010: Natural Solutions: Protected areas helping people cope with climate change. IUCNWCPA, TNC, UNDP, WCS, The World Bank \& WWF, pp. 126, Gland, Washington DC, New York.

Ford, D. \& P. Williams, 2007: Karst Hydrogeology and Geomorphology. Wiley, pp. 562, Chichester.

Gorman, C.F., 1972: Excavations at Spirit Cave, North Thailand: some interim explanations.- Asian Perspectives, 13, 80-107.

IMC, 1986: Preliminary Appraisal of the Hydrogeology of the Lower Mekong Basin. Interim Mekong Committee.

IRO (International Rivers Organisation), 2009 : Nam Ou.- [Online] Available from: http://www.internationalrivers.org/files/Lao\%20dam\%20data_Jan08. pdf [Accessed 25 June 2009].

IPCC, 2007: Climate Change 2007: Synthesis Report Contribution of Working Groups I, II and III to the Fourth Assessment Report of the IIPCC. IPCC, Geneva.

Issacs, H.R., 1967: No Peace for Asia.- MIT Press, pp. 295, Cambridge.

Kazuki, S., 2006: Sector Plan for Sustainable Development of the Mining Sector in the Lao PDR. Final Report. The World Bank, pp. 66, Washington DC.
Kiernan, K., 1987: Soil erosion from hilltribe opium swiddens in the Golden Triangle, and the use of karren as an erosion yardstick.- Endins, 13, 59-63.

Kiernan, K., 1988: The Management of Soluble Rock Landscapes. Speleological Research Council Ltd, pp. 61, Sydney.

Kiernan, K., 1989: Soil and water degradation in carbonate rock terranes.- Australian Journal of Soil \& Water Conservation, 3,4, 26-33.

Kiernan, K., 2010a: Distribution and character of karst in the Lao PDR.- Acta Carsologica, 38, 1, 65-81.

Kiernan, K., 2010b: Human impacts on geodiversity and associated natural values of bedrock hills in the $\mathrm{Me}$ kong Delta.- Geoheritage, 3-4, 101-122.

Kiernan, K., Spies, J. \& J. Dunkley, 1988: Prehistoric occupation and burial sites in the mountains of the Nam Khong basin, northwestern Thailand.- Australian Archaeology, 27, 24-44.

Lal, R., 2004: Soil carbon sequestration impacts on global climate change and food security.- Science, 304, 1623-1627.

LDGM, 1991: 1:1.000.000 Scale map of Geological and Mineral occurrence map of Lao P.D.R, 1:1 000000. Department of Geology and Mines, Government of Lao, Vientiane.

LNCDCS (Lao National Commission for Drug Control and Supervision), 2002: Opium Survey 2002.United Nations Office for Drug Control and Crime Prevention, Illicit Crop Monitoring Programme, Country Office Lao PDR, pp. 27.

McCoy, A.W., 1972: The Politics of Heroin in Southeast Asia. Harper \& Row, Singapore.

Middleton, G. \& K. Kiernan, 2009: A visit to some caves and karst of Vietnam and Laos - September-October 2008.- Journal of the Sydney Speleological Society. $53,11,293-317$.

Milanović, P., 2004: Dams and reservoirs on karst. In: Gunn, J. (ed.) Encyclopedia of Caves and Karst Science.- Fitzroy Dearborn, pp. 277-279, New York.

Reynolds, T.E.G., 1990: The Hoabinhian : A review.- In: Barnes, G.J. (ed.) Bibilographic Review of Far Eastern Archaeology.- Oxbow Books, pp. 1-30, Oxford.

Sayavongkhamdy, T., Bellwood, P. \& D. Bulbeck, 2000: Recent archaeological research in Laos.- Bulletin of the Indo-Pacific Prehistory Association, 19, 101-110.

Sidisunthorn, P., Gardner, S. \& D. Smart, 2006: Caves of Northern Thailand, River Books, pp. 392, Bangkok. 
Sinohydro, 2010a. The International Company Signed Development Agreement of Nam Ou Hydropower Project BOT Item with Lao Government. [Online] Available from: http://www. sinohydro.com/english/portlet?pm_pl_id=7\&pm_ pp_id=19\&ARTICLEID $=11927544590001 \quad$ [Accessed 20 July 2009].

Thongmanivong, S. \& Y. Fujita, 2006: Recent land use and livelihood transitions in northern Laos.- Mountain Research \& Development, 26, 3, 237-244.

Souphasay, K., 2008: Water Resources Management in Lao PDR. Presentation to 1st Working Group Meeting of the Project on Asian Environmental Review, 31 July 2008, Manila. [Online] Available from: http://www.iges.or.jp/en/ea/pdf/activity080731/09 Souphasay.pdf accessed 4 March 2010) [Accessed 15 June 2010].

Trudgill, S.T., 1976: The erosion of limestone under soil and the long term stability of soil-vegetation systems on limestone.- Earth Surface Processes, 1, 31-41.
UNODC, 2007: Opium poppy cultivation in South East Asia 2007.- United Nations Office on Drugs and Crime, pp. 134.

White, J.C., Lewis, H., Bounheuang, B., Marwick, B. \& K. Arrell, 2009: Archaeological investigations in northern Laos: new contributions to Southeast Asian prehistory. Antiquity 083 (319). [Online] Available from http://www.antiquity.ac.uk/projgall/white319/ [Accessed: 20 June 2010].

Yi, S., Lee, J., Kim, S., Yoo, Y. \& D. Kim, 2008: New data on the Hoabinhian: investigations at Hang Cho Cave, northern Vietnam.- Bulletin of the Indo-Pacific Prehistory Association, 28, 73-79.

Yuan, D., 1988: On the karst environmental system.- In: Karst Hydrogeology and Karst Environmental Protection, Proceedings, $21^{\text {st }}$ Congress, International Association of Hydrogeologists, Geological Publishing House, 30-46, Beijing. 